\title{
Social Network of Bugis Weavers at Wajo Regency, South Sulawesi
}

\author{
Muhammad Syukur $1 \bowtie$ \\ ${ }^{1}$ Sociology Education Study Program Faculty of Social Sciences, Makassar State University
}

DOI: http://dx.doi.org/10.15294/komunitas.v8i1.3437

Received : 30 March 2015; Accepted: 28 March 2016; Published: 31 March 2016

\begin{abstract}
The penetration of market economic system and the development of weaving technology within Wajo society has polarized Wajo weavers into three groups, Gedongan weaver, ATBM weaver and weaving entrepreneur. It indicates a different economic action conducted by those three groups in responding the economic market and technology development. This research aims to describe the moral basic in developing and utilizing network in weaving activities practiced by the three groups. The research uses qualitative approach with constructive paradigm. Data collection techniques used are in-depth interview method, participative observation and documentation. Data is analyzed using data reduction, presentation and conclusion. Research result indicates that production and distribution network of weavers involve social solidarity and economic interest and those networks take place in the form of horizontal and vertical relationship.Gedongan weavers use social solodarity network more than economic interest network. ATBM weavers tend to be in between solidarity and economic interest. Whereas, weaving entrepreneur use economic interest network more than solidarity network.
\end{abstract}

Keywords: social network; moral; weaver; Bugis-Wajo

\section{INTRODUCTION}

Every economic system adopted by a society always involves the actions of the people who become owners of the economic system. Related to community economic measures, there are two conflicting poles of thought, that is, the stronghold of undersocialized having a view that economic action is always oriented towards achieving the benefits (utility), and the issue of profit or loss is the main thing to be considered (cost - benefit ratio). While the other camps are oversocialized hand, stating that economic action is guided by the rules in the form of values and norms internalized through socialization process.

Granovetter $(1985,1992)$ took a middle ground between the two opposing camps by stating that economic action is socially situated and can not be explained by reference to individual motives and values espoused.
As a form of social action, economic action is embedded in network of personal relationships and social institutions than those made by the actor.

The presence of a global economic system that goes through trade and colonization into the economic system of society in Wajo, affect social life order, especially in weavers community activities. Weaving activities in South Sulawesi, which has been existing since the 13th century was initially made only to meet their own needs of daily clothing and customary fashion, but in its development, in about the 14th century and the $15^{\text {th }}$ century, the weavers who produce sarong have started to comercialize thir product in limited quantities.

Weaving activities grew more after the Indonesian independence by the use of Non-Machine Weaving Tools (handloom). However, this development does not ne-

\footnotetext{
Corresponding author:

Address: Jalan A.P. Pettarani, Kampus UNM Gunung Sari Baru Makassar, 90221

Email : syukurmuhammad10@gmail.com p-ISSN 2086 - 5465 | e-ISSN 2460-7320 
cessarily eliminate the loom called gedogan from weaving activities in South Sulawesi. The use of Non-Machine Weaving Tools (handloom) in Wajo started since the 1950s. In 1980 s, various weaving entrepreneurs appear in Wajo which employs weavers who did not come from a family member and was paid in a certain amount of money (Armayani 2008). Weaving production increasingly varied, in addition to sarong with a Bugis motif, it was also manufactured various kinds of fabrics such as; plain-texture silk fabric, selendang, clothing materials, custom fixtures, household, hotel and office accessories. In other words, the production of woven has adjusted to the market demand or consumer tastes.

The penetration of the global economic system into the weaving activities in South Sulawesi changed social and economic life order in the weavers community. This phenomenon is characterized by the presence of three groups of weavers who have the economic measures that differ from each other. This phenomenon is particularly pronounced when Non-Machine Weaving Tools (handloom) began to be used in the 1950s. Weaving economic system slowly and partly changed form the traditional and autonomous production and distribution to production and ditribution which is involved in a network of social structures and dependant one with others. Meanwhile, cultural changes as weavers was marked by a shift in the orientation of production. Production which previously was for family and customary purposes, changed to a production to meet market needs in order to pursue profits and accumulate capital. The values that aims to pursue profits and accumulate capital penetrated into most of the handloom weaving businessman. On the other hand, there are weavers who produce in traditional ways.Top of FormBottom of Form

In Wajo, there are approximately 5,113 gedogan weavers. There are 1,914 Non-Machine Weaving Tools (handloom), which is approximately $75 \%$ or 1,435 of them is owned by weaving enterpreneurs and 479 is owned by household scale handloom weavers, while only one entrepreneur has a \pm 25 pieces of Looms Machines (Machine Weaving Tools). (processed secondary data 2012). The presence of these three groups of weavers who coexist in one region becomes interesting to study because each weaving group has a different action in weaving activities. This problem can be traced through the analysis of weavers' economic action linkage associated with the differences in the moral basis for building and utilize business networks.

\section{RESEARCH METHODS}

This is a qualitative research using case study strategy. Case study is chosen for the peculiarities of the problem in addition to its ability to explain in a more deeply a social phenomenon (Cresswel 1984). Case study in the tradition of qualitative research allows the interaction between researchers and the researched as in the tradition of critical paradigm. Truth is a common understanding on a social reality in the form of intersubjectivity born as a result of the interaction between researchers and the researched (Denzin \& Lincoln 2000).

Data collection was done by using in-depth interviews (depth interview) and regular interviews to be conducted by researcher in a state as naturally as possible, Focus Group Discussion (FGD), participant observation, documentation and literature. Observations involved in the context of this study should not be interpreted that the researcher must be local residents and become directly involved in the activities of weaving. Attitude to feel a part of them or the ability to feel what is being experienced by the subjects (researched), could be interpreted by participatory observation.

Data were analyzed using an interactive model of Miles and Huberman (1994). The research data that has been collected is then processed and analyzed using qualitative analysis techniques with the following steps; data reduction, ie the process of selection and concentration and simplification, abstraction and transformation of the raw data in the records of interviews and observations obtained in the field; presentation (display) of data which is a set of informa- 
tion that has been arranged which gives the possibility of meaning that can be reported in drawing conclusions; drawing conclusions and verification is done after the data is presented, described and given meaning by a logical interpretation. Drawing conclusion is based on the data display and data reduction. Verification of data is done by intensive observation and triangulation (Moleong 1999). Data validity checking is also done in four ways, namely: degree of trust (credibility); transferability; dependability; certainty (confirmability).

\section{RESULT AND DISCUSSION}

\section{The Preference of Weavers in Network- ing}

Bugis Wajo people's view about the success of a business is that it is determined by the help of others, hard work and self-perseverance as well as the blessing of God. Awareness of the need for help from others in developing their businesses make the creation of social networks be a very important thing to be built. The development of Wajo weavers' social networks outside the Wajo territorial is done by tracking the businessmen in the the targeted area, with considering the background of kinship, regionalism (fellow Wajo - Bugis), friendship, ethnicity (Bugis ethnic). If in an area, there is no Bugis who is willing to establish business cooperation, only then the choice dropped to other ethnic groups. The development of such network is rooted in the principle of the Bugis "silellung Sirui" (chasing and draw each other) as an important asset in building constructive rivalry in business.

Wajo Bugis prefer involving relatives in running a business. If there is no relative to cooperate with, the next choice is the fellow Wajo Bugis, the next choice is a fellow Bugis ethnic and the last choice is other ethnic groups. Consideration prioritizing relatives in running a business networks is due the emotional and intimate incestuous relationship that make the network member know each other, and the trust that is built has been very strong. Cooperation with relatives in the marketing of woven cloth out- side the Bugis area does not just involve business cooperation but also has another dimension, namely to relieve homesickness among family. Relatives staying outside Bugis could ask about their family in Bugis and the condition at home while the Wajo travelling outside can listen to the story of the struggle of life experienced by overseas relatives.

Bugis diaspora to different areas of the archipelago even to foreign countries become social capital in building a business network or marketing development of $\mathrm{Bu}-$ gis woven fabric. Bugis people who wander usually hold their customs. Various traditional celebrations held in the seacoast area requires them to use a Bugis woven fabric. Therefore, every household has always tried to have Bugis woven fabric which is prepared for traditional ceremonies. The use of Bugis woven fabric in Bugis ceremonies for immigrants is a symbol of identity in the community where they settled.

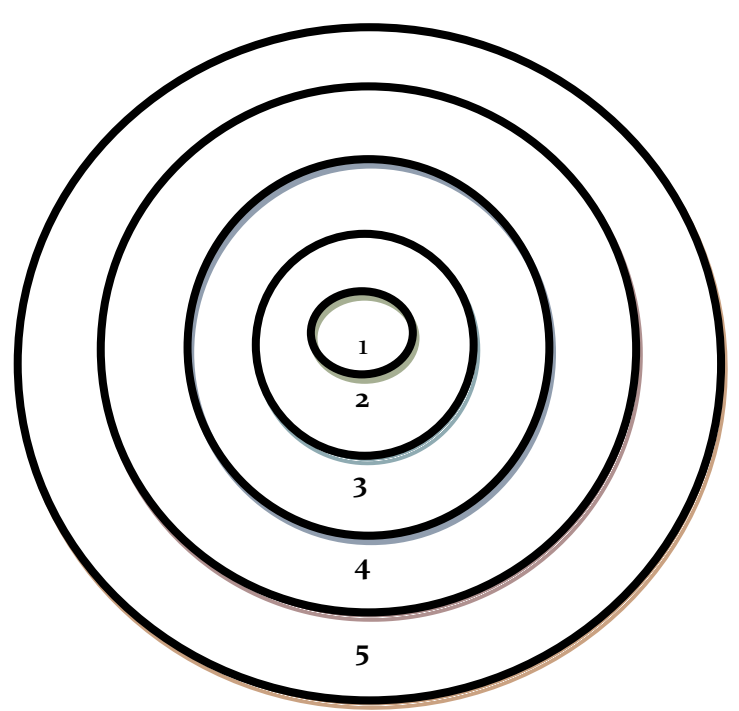

Figure 1. The Preference of Bugis Weaving Business Network

Sorce: Processed Field Data, 2014

Note:

1. Kinship/Relatives Network (Selessureng/Sumpunglolo)

2. Regional Network (Sikampong)

3. Friendship Network (sahabat)

4. Ethnic Network (Sempugi)

5. Other Ethnics Network (to lain) 
Based on picture 1 , the reference for the establishment of weavers business networks can be concluded that the smaller the circle, the more cohesive the relationships network, and the higher the likelihood for the creation of mutual trust. Business network run by weavers is a bridge and adhesive in developing the business. Various convenience gained from their business network can be seen from various facilities obtained by a man or a group to access a variety of resources such as information, goods, services, price, power and so on.

Based on Bugis social system, relationship network is established by bilateral kinship system where kinship in the Bugis community is drawn based on the relationship of the father and mother. The network is called masselessureng/sumpunglolo (kinship / relatives relationship). The social network which refers to sikampong (compatriot) is the relationships formed through the similarity of area of residence. The social network which refers to the bonds of friendship can be referred to the similarities of the school, organization, taste, and others. While sempugi (intra- Bugis ethnic) refers to the social networks formed by tribal bonding, that is a person from the same tribe, but come from different areas. As explained earlier, the Bugis inhabit several districts in the province of South Sulawesi. Preference of business cooperation is made to other ethnics (circle 5) if there is no businessmen on the circle $1,2,3$, and 4 .

\section{Weavers Network in Production Activi- ties}

Production activities are socially organized process in which goods and services are created. Production activities undertaken by gedogan weavers often resulted in their spending all time to produce goods from raw materials to a ready for use product. Gedogan weavers usually serve as merchants as well who sell the final products. Gedogan weavers are more independent and highly autonomous in relation to production. The dependence on outside parties is only on the availability of capital and procurement of yarn.
Strong network owned by gedogan weavers with their family, neighbors, and fellow gedogan weavers provide a greater motivation basis to provide assistance. The strong solidarity built in gedogan weavers network is characterized by their solidarity and intensive meetings, intimacy, and reciprocal behavior. A strong trust arises from a very intensive and intimate relationship allowing them to know each other's personality. The structure formed by these emotional relationships tend to be more stable and permanent. There is a mechanism that serves to ensure the stability of structures that involve norms and values that can restrict a social act that interferes the permanence of the structure.

Strong network occurs among adjacent gedogan weavers living in a village. The relationship between them occurs not only through helping each other in the weaving activities but also helping each other in social activities. Gedogan weavers share information about different types of patterns, motifs and color of woven fabrics in demand in the market. Although seen as though they are competing in the market in the production of woven fabric, they did not consider their fellow weaver as a rival. Activities to share information on various matters related to weaving activities has become a habit amongst gedogan weavers. The efforts of fellow gedogan weavers to gain market share for the produced woven fabric is not meant as a competition, because in their view, everyone has their own fortune that has been set by Allah SWT. This kind of understanding bore a harmonious relationship between them and caused no dispute.

Social relations through a strong network that is based on an emotional relationship usually tends to be a close and fused relationship. Among the actors involved, there is a tendency to like each other or do not like the behavior of other actors in the network. Relatively strong social control among actors facilitate the emergence of values and norms that serve to develop network continuity. As a result, this strong network will generate a sense of solidarity, in which the actor tried to reduce his personal interests. 
Act of giving and receiving (reciprocal) between the actors is traditionally patterned. The principle of reciprocity is inherent in the culture of the Bugis Wajo forwarding a relationship on the basis of sibali perri (helping in distress) and sibali reso (helping in the work).

Rationality of gedogan weavers to produce woven fabric with nobility pattern for the noble showed two rationality that works, that is, traditional rationality and instrumental rationality (Weber 1978). The division of rationality is indicated by their desire to obtain economic benefits on nobility pattern woven fabric, but on the other side, they also have traditional rationality where their is based on the habits of the past and is still practiced and accepted without any reflection. Justification often cited by gedogan weavers is that it is the way that has been done by their ancestors that has lasted for generations.

Solidarity with fellow weavers is also conducted in getting raw materials. Gedogan weavers often deposit money to neighbors to buy yarn in the market. Solidarity with relatives and neighbors is always maintained, because relatives and neighbors always become an intermediary in buying and selling activities between the weavers and their customers without asking for recompense. Cutbacks in household consumption is done when the weavers do not get sales order by not attending the wedding invitation in order that the money they have can be used to meet the needs of the household. This is in line with the findings of Hefner (1983) on the Tengger people in East Java stating that the people also tends to reduce family consumption and ritual feast upon the bad financial condition of a family

Social networks formed between gedogan weavers and yarn merchant who is not in close relationship are weak networks. This kind of networks are bound by an interest in which gedogan weavers want to get the yarn for weaving needs while yarn traders want to get benefit from yarn they sell. When both parties get benefit from the activity of selling yarn, the network formed between them is going to be broken. Me- anwhile, social networks formed between gedogan weaver with loyal yarn traders are more robust network. Trust between them is very strong. Their relationship is very intimate and often amid the purchase transactions, they tell each other about their problem and life experiences. This relationship is often continued to a more intimate one by inviting each other to attend wedding or other celebration, even the relationship can influence the similarity in political choice. Various social network owned by gedogan weavers are dyads (a pair) and triads so that the analysis is to highlight the structure of relationships, equality and social inequality and the tendency of exchange.

Meanwhile, the handloom weavers also has a strong network built by neighbors and relatives as well as friends and provide greater motivation basis to provide assistance. Strong network among handloom weavers is characterized by emotionally-intensed relationship, intimacy, and reciprocal behavior. The relationship is based on the emotional relationship that involves a sense of kinship and friendship. Mutual help between neighbors, relatives and friends is a common in the social life of the handloom weavers. However, the activities of helping is not found in the weaving activity because weaving activities has involved services and wages.

Social networks formed among neighboring handloom weavers is a robust network. This network is bound by emotional ties and economic interests. The relations occurs through mutual help in social activities, not in weaving activities. Various weaving activities have involved the exchange of money and services. The handloom weavers share information about a variety of types of patterns, motifs and color of woven fabric which is sold out in the market. Although they look like competing each other in marketing their woven fabric, they do not consider his fellow weavers as rival. The share of information among handloom weavers reflects their bonds of solidarity and economic interests, while the use of wages in weaving activities show their economic interests.

Social network between handloom 
weavers and yarn and dye merchants is strong. Although social networking that occurs among handloom weavers with yarn traders is strong (intimate and intensive), the relationship between the two tends to be vertical (hierarchical). The network is tied by emotional relationships and interests. The emotional connection arises because they are familiar with each other and often meet. This relationship involves the sense of belonging to the same Wajo-Bugis and part of the third circle in the weavers reference in building network. Relations between the two sides lasted disproportionately because one party has a stronger force than the other party, or a patron-client relationship. These symptoms is consistent with Willer (1999) opinion stating that social network could form a relationship that is both vertical and horizontal. This study shows that social network among handloom weavers and yarn traders place the handloom weavers in the position of clients (men) while the yarn trader in the position of patron (retainer / boss). Networking among handloom weavers and merchants is based on mutual economic need, but in reality the relationship is unequal. Handloom weavers tend to be subject to different rules of the game set by the yarn trader such as the amount of interest established, repayment and othersTop of FormBottom of Form.

Social network formed between handloom weavers and weaving workers is a strong network. The preference of handloom weavers in recruiting weaving workers is based on consideration of kinship. Social networking among handloom weavers and workers involves their emotional relationships, interests, and power (strength). The emergence of emotional connection in the network of handloom weavers and the workers is based on solidarity on the basis of kinship so that it tends to be more stable and harmonious. Networking among handloom weavers and the workers also involves interest. Handloom weavers want to get benefit from the sale of woven fabric produced by the workers, while the workers wanted to get wages from woven fabrics. These relationships involve an economic objective to be achieved by each actor. In this study, it is found that the breaking collaboration between handloom weavers and labors does not simultanously break social networks between the two. This condition occurs because of the interconnections between emotional ties and interest relationships in the social networking between handloom weavers and the workers. The relationship between the two is not only bound by the logic to get profit or merely economic relations (interests), but also bound by emotional ties on the basis of kinship.

Social network between handloom weavers and the workers involves the power (force) that puts the handloom weavers as a power center or a boss / Ponggawa (patron) while the workers are client. Power center (handloom weavers) has authority to review the performance and control all activities in the organization of production. Social networks involving power can not rely on the consciousness of its members to fulfill their obligations voluntarily, without any incentive. Therefore, informal distribution of rewards and sanctions is necessary to support the emergence of the willingness to accept the values and norms set by the central power.

Social networks arising between loom businessman and the relatives, neighbors and friends is a strong network. Relations between them are bound by emotional relationship. Intensive meeting durability wrapped by a sense of kinship, regionalism and common fate still characterize the relationship between them. Mutual assistance in the form of physical and material involvement in the life cycle events associated with rituals of grief like death is always done. While the lifecycle events associated with excitement (marriage, aqiqah, circumcision, etc.) are not to be done with physically involved in these activities, but financially they are involved. Weaving employers often send a donation envelope (Passolo) as a sign of their involvement in the life cycle events associated with excitement.

Networking between weaving entrepreneurs and the workers also involves economic interest, emotion (solidarity) and 
power (strength). Weaving employers want to get benefit from the sale of woven fabric produced by the workers, while the workers wanted to get their wages from woven fabrics. This relationship involves the objectives to be achieved by each of the actors in the network. When these goals have been achieved, usually the relationship can not be sustained. In the context of this study, the broken cooperation in employment between loom employers and the workers does not simultanously break the social networks taking place between the two. Emotional relationships arise because they come from similar fellow Bugis (sempugi). Relations between the two are often continued in the event of inviting one another in a celebration. This condition occurs because of the interconnections between emotional and interest relationships in the social networks between weaving employers and the workers.

Social networking between looms weavers and the workers involves the power (force) which puts the looms weavers as the central power or the boss / Ponggawa (patron) while the labors are in subordinate (the client). Social networks involving power can not rely on the consciousness of its members to fulfill their obligations voluntarily, without any incentive. Therefore, informal distribution of rewards and sanctions is needed to bring about the willingness to accept the values and norms set by the central power. Looms weavers employers as patron give the assurance of income and security for the client. They also give a donation if there is the family of the labors get unfortunate.

The social network owned by a group of handloom weavers and weaving entrepreneurs form a sort of patronage networks. The networks put handloom owners and weaving entrepreneurs as patron and weaving workers as a client. There is economic and social benefit in the patronage relations in weaving activities. Weaving workers have an economic gain in the form of wages from work and the availability of jobs at the time they did not work in the fields to harvest. However, the flow of economic benefits is enjoyed more by the handloom weavers and weaving entrepreneurs compared to the weaving workers. This is in line with the findings of Mirajiani, et al (2014) stating that the material benefits in the patronage network of fishermen flow more to the patrons, but the client also receives a guarantee of jobs, provision of capital, infrastructure and marketing services.

Social network between weaving entrepreneurs and yarn and dye enterpreneurs is characterized by a weak network. Ties that bind the network is the interests for mutual benefit of the sale and purchase transactions performed. Weaving employers sometimes borrow money from yarn entrepreneurs without collateral goods and the agreement made in a sheet of paper (Sadapotto 2010).

Dyes are generally purchased in cash at entrepreneurs in Sengkang and Makassar. In fact, sometimes there are businessmen who buy weaving dye in Surabaya and Jakarta. The social network created between weaving employers and dye trader in Makassar, Surabaya and Jakarta, is a weak network. The bonds between them is covered by their economic interests for mutual benefit of the business transactions they perform. The less intensity of meeting create a weak trust between them. This social reality is in accordance with the view of Granovetter $(1973,1985)$ stating that social structure and network can affect economic results such as labor recruitment, price, productivity and innovation.

Referring to the concept developed by Willer (1999) that there are two types of networks, that is social and economic networks, the authors can categorize that the networks owned by weaving enterpreneurs rely more on economic rather than social network, while the network developed by gedogan weavers and handloom weavers is more on social than economic network.

\section{Weavers Network in Distribution Activi- ties}

Bugis woven fabric marketing system occurs through a process of exchange of money and goods (fabrics) in the market. Woven fabric produced by the weavers in Wajo distri- 
buted in markets, both markets in terms of place and market as a concept. Place market which became a place of te distribution of Bugis woven fabric is spread throughout the subdistrict in Wajo regency and the Sengkang central market. While the market in economic concept is where Bugis woven fabric can be distributed anytime and anywhere without being bound by the existence of a certain place and time.

The marketing of Gedogan woven fabric is not only in markets, but sometimes there are buyers who come directly to the gedogan weavers house to book a woven fabric according to their tastes. There are also big traders and weaving businessmen who came to gedogan weavers' home to buy a woven fabric. The marketing system of woven fabric most commonly run by gedogan weavers is selling the product in the market. The pricing of the woven fabric is determined through the mechanism of bargaining between the seller (gedogan weavers) and buyers (traders). Bargaining is the typical pattern of pricing in the sale and purchase transactions conducted by gedogan weavers. Bargaining usually takes a considerable time, so time is not a scarce and valuable resource, as in the market of modern industrial society. In contrast to modern capitalism where the prices of goods and services are determined by abstract forces of demand and supply, in gedogan weavers marketing system, person can go shopping in the store and find exactly the price specified for certain goods.

Based on Figure 2, it can be understood that the channels of distribution (marketing) of woven fabric produced by gedogan weavers take two ways, namely direct and indirect distribution. Direct marketing happens when consumers come to gedogan weavers' home to order or buy goods. While indirect marketing goes through: neighbors, relatives and friends; traders; weaving businessman; and traditional institutions. There are regular consumers who booked woven through neighbors, relatives, and friends of the gedogan weavers. Gedogan weavers most often use the collected traders path to sell their products. Traders at district and regency level sell the product directly to consumers, and some products are sold to provinces wholesalers. Province traders sell products to merchants in several regencies in South Sulawesi and partly sold to inter-island traders. There are also consumers who purchase goods to the province

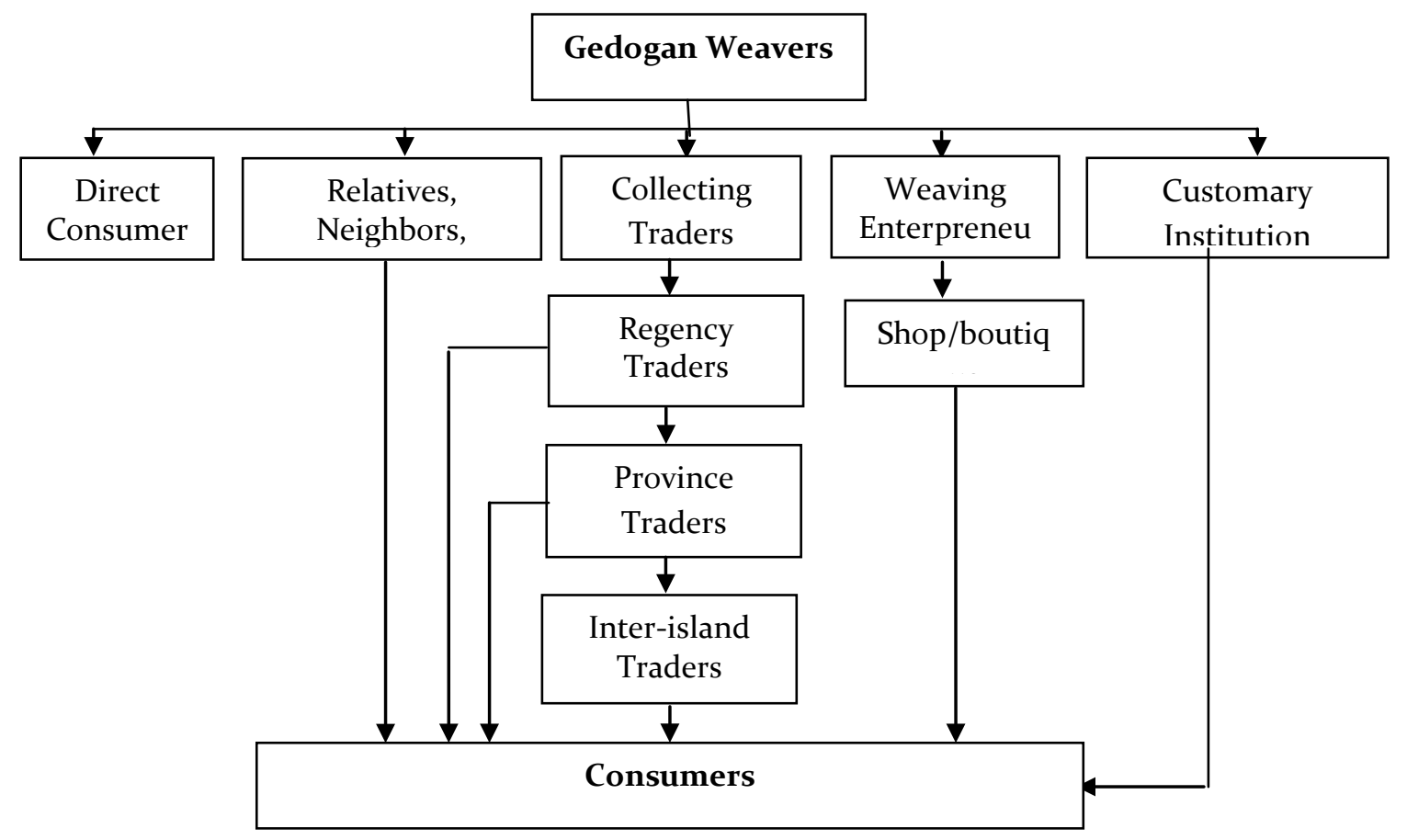

Figure 2. Distribution Route of Source: Processed Field Data, 2014. 
merchants. Weaving enterpreneur also often buy woven fabric produced by gedogan weavers for their sale in the store or boutique. The last track used by gedogan weavers gedogan in the distribution of fabric is customary institutions. Social networks formed between gedogan weavers and loyal traders / pappalele is a robust network. Although the network is formed on economic interest, because of the intensity of the meetings the trust that appears between them is very strong. The relationship between the two is not only in sale and purchase transactions, but continues on a regular inviting each other to a wedding or other celebration.

Social networks formed among neighboring handloom weavers is a strong network. Relations between the two occurs through mutual help in social activities but not in weaving activities. Various events in weaving activities have involved the exchange of money and services. The handloom weavers share information on various things such as types of patterns, motifs and color of woven fabric which is sold out in the market. Although they look like competing each other in marketing their woven fabric, they do not regard other weavers as rivals.
Handloom weavers generally use market place for the marketing of their products, but there are also consumers who come to their house to buy woven. The product of handloom weavers is usually entrusted to some merchants who sell it in the market. The pricing of fabrics produced by the handloom weavers is determined by prevailing market mechanisms at the local level. Woven fabric purchased from handloom weavers by the traders is then distributed to dealers in Makassar Mall and Butung market in Makassar. Traders in Makassar sells the cloth partly in Makassar, and others are sold in various regions outside South Sulawesi.

Based on Figure 3, it can be seen that the distribution channels used by handloom weavers are direct and indirect distributions. Direct distribution occurs when consumers come to the house to buy handloom weavers woven fabric. While the indirect distribution channels uses three distribution channels, namely: neighbors, relatives, and friends; traders; and weaving businessman. Like gedogan weavers, handloom weavers also use relatives, neighbors and friends as a marketing channel. There

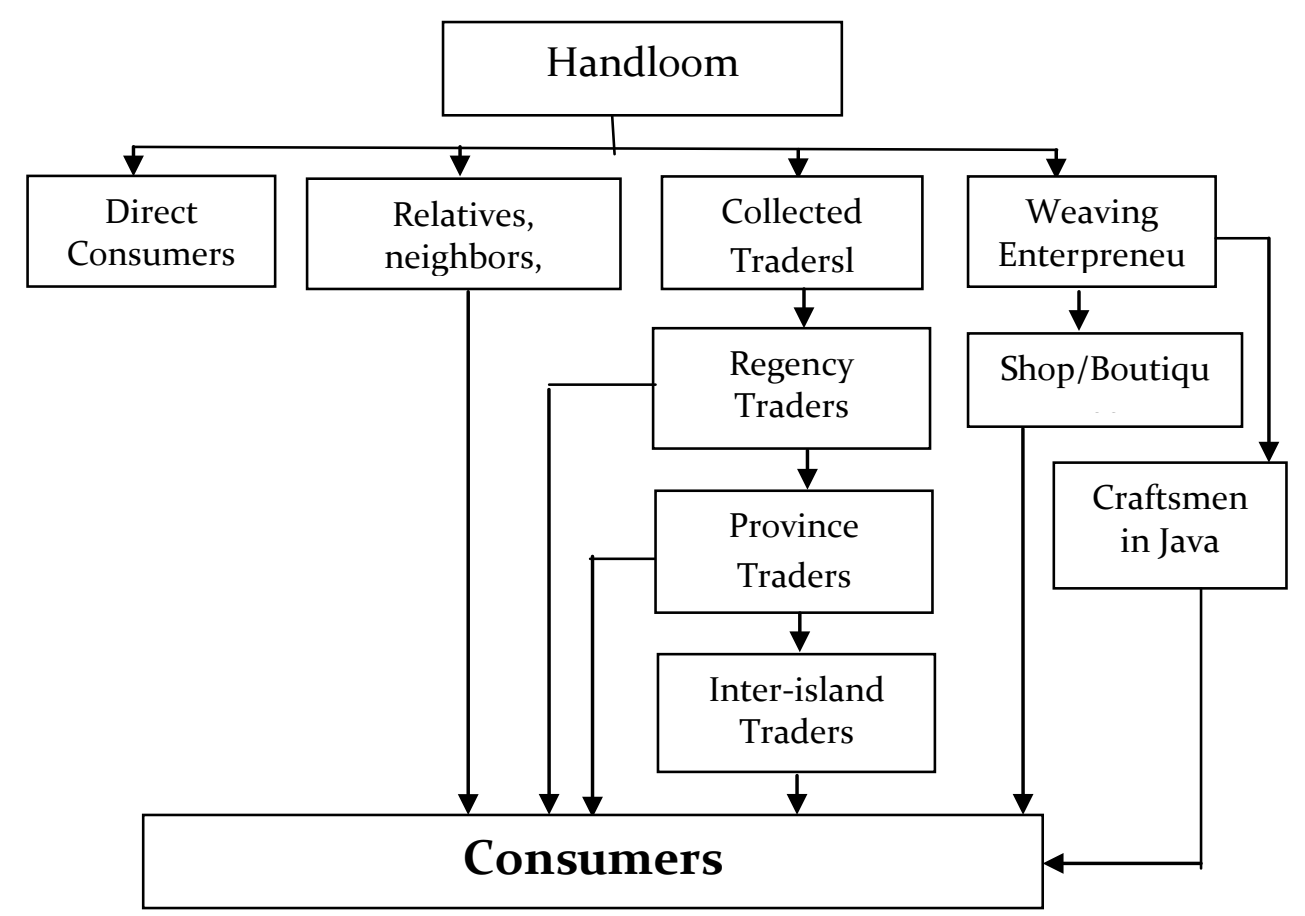

Figure 3. Distribution Route of Handloom Weavers

Source: Processed Field Data, 2014. 
is a tendency that some consumers who will buy fabric at a low price but do not have direct access to the handloom weavers, they will use relative, neighbor, or friend as the channel. Handloom weavers-would often ask relatives, neighbors and friends to help them market their woven fabric production. So relatives, neighbors and friends often serve as intermediaries between the handloom weavers and consumers in the marketing of woven fabric. The most common paths used by handloom weavers in marketing activities is through middlemen or traders in district level. Then, from the district level there are traders who sell the product directly to consumers and some distribute it to traders in provincial level. Tradersin provincial level generally has a clothing stall at malls and markets in Butung Makassar . From them, the product is sold directly to consumers or to traders in several districts in South Sulawesi or to inter-island traders. The last track used by handloom weavers in marketing is through weaving businessman. As explained previously, handloom weavers are often being the sub agent of weaving businessman. When the weaving businessman gets woven fabric orders in large quantities, they handed most of these orders to handloom weavers to do with a contract system. Then, cloth produced by handloom weavers is distributed back by weaving businessman through batik entrepreneurs in Java. Woven fabric marketed by weaving businessman to batik businessman in Java is generally woven in the form of plain textures. Next by batik entrepreneurs in Java, batik fabrics are subsequently sold to consumers. There is also weaving businessman who directly distribute woven fabrics produced by the handloom weavers to consumers.

Weaving businessman produce something with the primary objective is the market and they generally have a marketing network in some areas, even have a store or boutique in town of Sengkang and Makassar. Network marketing of weaving entrepreneurs is not only in the local market but has expanded to national and global level. Generally, weaving enterpreneurs in Wajo has large quantities of inventory and has al- ready started using the services of transport and delivery for distributing goods to various regions. Paying system of a large quantities of woven fabric sent to various regions do not always use cash, but sometimes use a checking account.

Product marketing of weaving entrepreneurs is through individual buyers, retailers, batik craftsmen, government and private institutions, traditional institutions, designers, as well as domestic and foreign tourists. There are individual buyers (direct consumers) who frequently shop at the fabric store / boutique in Sengkang and Makassar which is owned by weaving businessman. The relationship between direct consumers and weaving entrepreneurs is relatively short andpurely based on economic interest. So when transactions between weaving businessman and direct consumers has occurred, the relationship between them then is broken. There are also consumers who order goods through relatives, neighbors and friends of the weaving entrepreneur. The relationship between relatives, neighbors, and friends with weaving employers in a purchase transaction involving not only economic interests, but also emotional connection that is familial and friendship. Consumers who booked woven through relatives, neighbors and friends of the weaving entrepreneur usually get relatively cheaper price than consumers who buy directly to the employer without any emotional connection.

Weaving employers also serve purchases made by retailers in the district and the province. The distribution network between weaving employers and retailers in the district and in the province not only involves business interests but also emotional relationship. The frequent meetings took place between them and their economic interests make the network between them relatively last longer. Emotional relationships originate from family ties and regionalism or tribalism ties. Retailers in district level and provincial-level generally come from Wajo, Bugis Ethnic and some of them have family relations with weaving employers. Amid the business transaction, weaving enterpre- 
neurs and retailers often talk much about non-business talk. The trust between them is stronger because they know each other due to the frequent meeting and the similarity of place of origin and ethnicity. Ordinary business relations between them continue to inviting each other when they have a celebration.

Weaving enterpreneurs also often serve buyers at the shop. The buyers is ranging from domestic and foreign tourists. Domestic and foreign tourists are usually escorted by a tour guide. Enactment of the Pakkanna village in Tanasitolo District as a tourist destination in 2009, make weaving enterpreneur more often serve domestic and foreign tourists. Domestic tourists visiting the enterpreneur's shop is generally guest from government agencies in Wajo. While foreign tourists are generally escorted by tour guides from tourist trips in the city of Makassar. Network formed between weaving enterpreneur and domestic and foreign tourists are bound by their economic interests in the absence of emotional connection. Although weaving enterpreneur serve both domestic and foreign tourists well, business transactions between thme are rarely repeated.

Weaving enterpreneurs also have a network with local customary institution and some other customary institutions. Weaving entrepreneurs often get orders from traditional institution in Wajo and various traditional institutions in South $\mathrm{Su}-$ lawesi. Even enterpreneurs in Wajo are also used to receiving orders from traditional institutions in South East Sulawesi. Networks that have developed between loom enterpreneur with local customary institutions do not only involve economic interests, but also emotional relationship. Loom businessman as the owner and supporter of $\mathrm{Bu}-$ gis culture have always had a responsibility to support various cultural activities carried out. The price offered by the businessman for local customary institutions is much lower than other traditional institutions that also often order goods to them. So, the network between weaving businessman and local customs agency did not only involve economic interests but also an emotional connection. While the relationship between loom businessman with agencies outside Wajo district, only involves their economic interests.

Weaving enterpreneurs also have network with government agencies and private sector. Some weaving enterpreneurs in Wajo often get orders from government agencies both in Wajo and various areas of South Sulawesi. The relationship between loom enterpreneurs and the government of Wajo in business transactions involves economic interests, emotional relationship and unbalanced strength (power). According to KS (48 years / weaving entrepreneur), Wajo government usually orders fabrics to several enterpreneurs when there is customary celebration in Wajo. However, woven fabrics ordered are usually not paid according to the price agreed in advance, so the businessmen suffer losses. The government also often include entrepreneurs in various exhibitions (eg tourism fairs, arts festivals, industries and others) in which there is a budget provided by the organizers or local governments to participate in the event, but in fact weaving enterpreneurs often have to pay for their participation. The condition shows that the government has power. Enterpreneurs often protested, but because they do not have enough strength to fight, so the act of the government is accepted although grudging. Enterpreneurs often take advantage of weaving exhibition activities for mutual exchange of information among the participants to allow new marketing network. According to KS (48 years), participation in exhibition is effective enough to expand marketing channels. Although the network between woven enterpreneurs and local authorities involves economic interests and unbalanced strength, this relationship is lasting because there is no other choice for them not to be connected. The government requires loom enterpreneurs to drive economic wheels in society, while the weaving entrepreneurs expect the government's role in regulating the development of natural silk in Wajo.

Network between weaving entrepreneurs and private institutions only involve 
economic interests and not lasting. When buying or selling happens, then this relationship is broken. Some hotels, restaurants and offices in Makassar also often order products of weaving entrepreneurs in Wajo. Weaving enterpreneurs continue to maintain the trust and quality of the goods that will be sold to the private sector, for fear that they'll no longer want to buy goods from them. Fabric sales to the private sector is usually accompanied by a written agreement and payment in cash. The goods will be paid by the private sector after the item is received. Payment can be done with cash or checking account. Weaving enterpreneurs in Wajo have also been cooperating with designers from Jakarta. Networking between weaving entrepreneurs and designers involves economic interests only.

Most of the fabric produced by weaving businessman are distributed to traders in Makassar (provincial level traders). Next, the provincial merchants distribute to consumers directly or to inter-island traders. The relationship between loom employers with provincial level traders is bound by their economic interests and emotional connection. Weaving enterpreneurs continue to maintain trust and relationships with provincial level merchants. The relationship does not only happen in business activities but also continue to inviting each other when there is a celebration.

Weaving enterpreneur always maintain good relations with their loyal consumers. The relationship between weaving employers and batik entrepreneur involves economic interests in which each wish to benefit. However, the relationship also involves power, where the batik enterpreneur has a stronger power than the weaving entrepreneurs. Batik entrepreneurs always sort the fabric they receive from weaving employers, and if it does not suit them, the fabric is not received. Weaving employers can do nothing if the woven fabric sold to batik enterpreneur was rejected.

Based on Figure 4, it can be understood that the entrepreneur run two distribution channels, namely direct and indirect distribution. Direct distribution occurs when consumers come directly to buy in the store / boutique owned by entrepreneurs. Consumers who buy directly from weaving entrepreneurs usually come from individual buyers of Bugis ethnic, domestic and foreign tourists, government and private institutions, traditional institutions, and

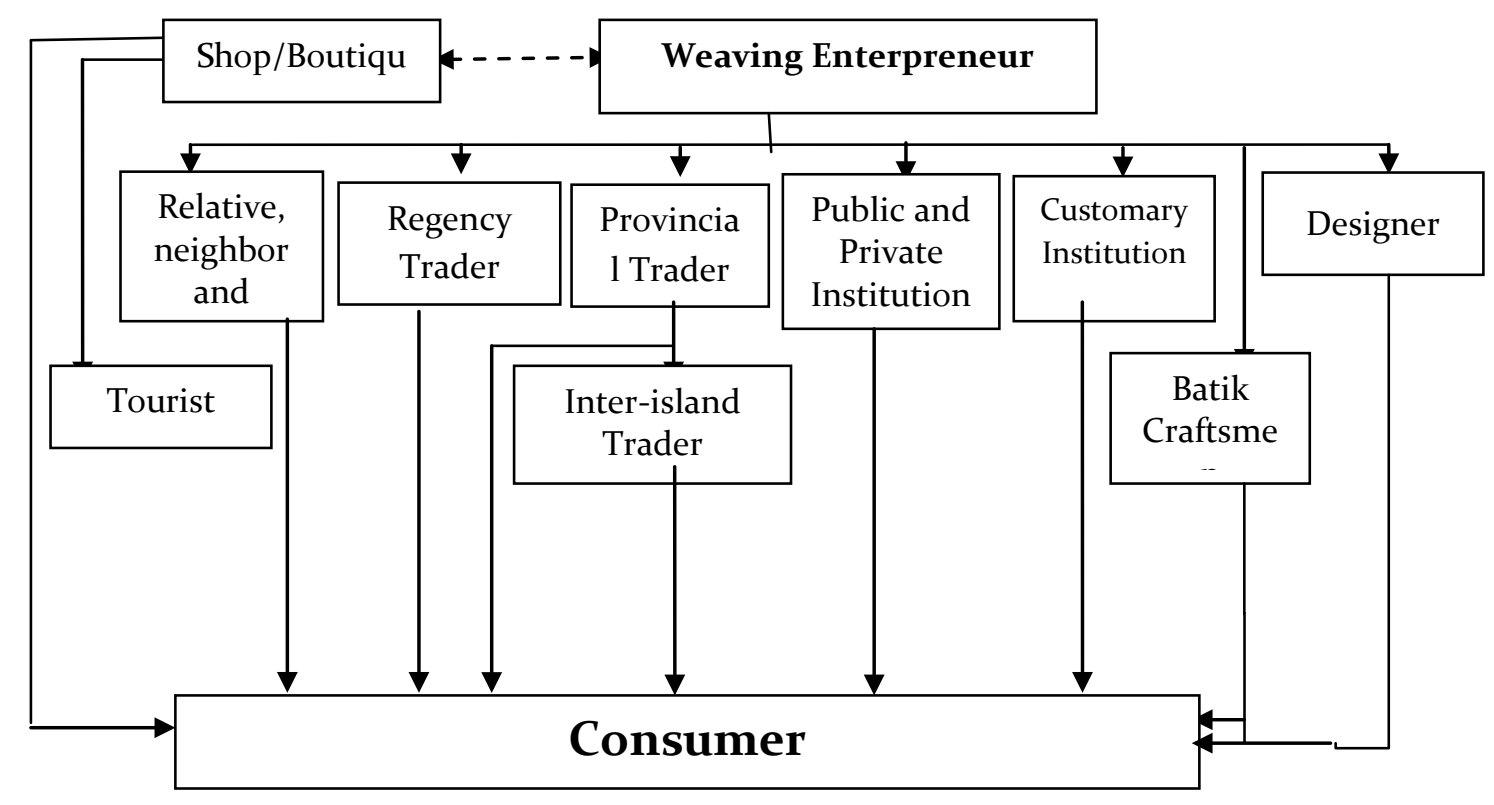

Figure 4. Distribution Route of Weaving Enterpreneurs

Source: Processed Field Data, 2014. 
fabric collectors. While indirect distribution occurs through designers, traders in district level, traders in provincial level, and batik craftsmen in Java. Fabric purchased by the designer is subsequently processed first into the apparel before being sold to consumers. While the fabric purchased by the district merchant is sold at the local level and partly sold to provincial level wholesalers. The provincial level traders sell a portion of the woven in Makassar and partly sold to the inter-island merchant. Weaving entrepreneurs produce woven fabric with plain textures which is generally distributed to batik craftsmen in Java. There is also woven enterpreneur in Wajo who used to get orders of plain crape (white) from the people of Bali for use in religious rituals.

The results of this research is line with Boissevain (1978) stating that social network is a social structure of society. Social networking is the social relationship between individuals, groups or organizations. The findings of this study indicate a relevance with the findings of Mitchell, (Scott, 1991) that the power of network is affected by reciprocity, the intensity and durability of the relationship between the parties.

Every social network (weak or strong) owned by weavers is committed to a bond / adhesive and support for smooth operation of the loom. The findings of this study fit Granovetter (1974; 1983) saying that any bond forms; weak or strong, providing ease in conducting business activities. There is a tendency that every actor involved in a network reduce personal interests. Social networks facilitate the mobility of resources. One of the strentgths of weaving businessman compared two other weaving groups in Wajo (gedogan weavers and handloom weavers) lies in the ability of weaving businessman in resources mobility. Weaving businessman's ability to mobilize the resources lies in its social network. This is in line with the findings of Powell and SmithDoerr (Smelser and Swedberg: 1994) about the importance of social networks in helping the ability to mobilize resources in the form of financial and information for business development. Weaving businessman in developing a business, does not only rely on their social networks at the local level, but they are also able to build social networks at national and global level. So it is different from the other two types of weavers which rely more on social networks at the local and supra-local.

\section{CONCLUSION}

Social network in weavers shows various types of social relations that are bound on the basis of kinship identity, race, ethnicity, friendships, neighborhoods, or certain economic interests. Basic morality of weavers in developing a network is rooted in the view that the success of a business is determined by the help of others, hard work and perseverance as well as the blessing of God. Wajo weavers in developing their business, attempting to find a social network that they may have in certain area by tracking the businessmen in the area by considering kinship relations, regionalism, tribalism and friendship. If they do not find any, the next choice is business partner from other ethnic groups (non-Bugis).

Type of social network in the three levels of weavers involving emotion (solidarity), interest and power (strength), hierarchical and horizontal order continually intersects. The type of social network owned by weaving businessman is larger and more bound by their economic interests and power rather than an emotional connection or solidarity. Gedogan weavers and handloom weavers network is very limited and more bound by their emotional connection or solidarity rether than economic interests and power. Relationships owned by gedogan weavers are more durable because it is wrapped by a sense of togetherness and mutual need of the actors in the network. The networks owned by weaving businessman tend not to last long, because if each actor in a network involving economic interests has achieved their objectives, the network will be broken.

\section{REFERENCES}

Armayani, et al., 2008. Profil Persuteraan di Kabupaten Wajo. Pemda Wajo, Sengkang. 
Biggart N.W., 2002. Readings in Economic Sociology. Blackwell Publishers, Malden, Massachusetts, USA.

Boissevain, J., 1978. Friends of friends: Network, Manipulator and Coalition. Basil Blackwell, London and Worcester Oxford.

Denzin, N.K. \& Lincoln, Y.S. (eds). 20oo. Handbook of Qualitative Research.(Second Edition), Sage Pul. Inc, Thousand Oaks.

Geertz, C., 1989. Penjaja dan Raja. Yayasan Obor Indonesia, Jakarta.

Granovetter, M., 1985. Economic Action and Social Structure: The Problem of Embeddedness. American Journal of Sociology. 91, pp.481-510.

Granovetter, M., 1973. The Strength of Weak Ties. American Journal of Sociology. 78(6), pp.136o1380.

Granovetter, M., \& Sweddberg, R., (edit). 1992. The Sociology of Economic Life. Westview Press, Boulder, San Francisco, Oxford.

Hefner, R.W., 1983. The Problem of Preference: Economic and Ritual Change in Highlands Java. Man. New Series. 18(4), pp.669-689.

Miles, B.M. \& Haberman, A.M., 1994. Analisis Data Kualitatif. UI Press, Jakarta.

Mirajiani, et al., 2014. Transformasi Pranata Patronase Masyarakat Nelayan: Dari Ekonomi Moralitas Menuju Ekonomi Pasar. Jurnal Komunitas. 6(1), pp.115-134.
Powell, W.W. \& Smith-Doerr, L., 1994. Networks and Economic Life. inSmelser, N. J. and R. Swedberg (editors). 1994. Handbook of Economic Sociology. Firts Edition. Princeton University Press, Princeton, New Jersey.

Sadapotto, A., 2010. Penataan Institusi Untuk Peningkatan Kinerja Persuteraan Alam di Sulawesi Selatan: Studi Komparasi di Enrekang, Soppeng dan Luoding City - Cina.Disertasi. SPSIPB. Bogor: Institut Pertanian Bogor.

Scott, J., 1991. Social networking analysis. Sage Publications, London.

Smelser, N. J. \& Swedberg, R., (editors). 1994. Handbook of Economic Sociology. Firts Edition. Princeton University Press, Princeton, New Jersey.

Sitorus, M.T.F., 1999. Pembentukan Pengusaha Lokal di Indonesia: Pengusaha Tenun dalam Masyarakat Batak Toba. Disertation. SPS-IPB. Institut Pertanian Bogor, Bogor.

Weber, M., 1978. Economy and Society: An Outline of Interpretatif Sociology. Vol. I (edited by Roth, G., and Wittich, G.). University of California Press, Barkeley.

Willer, D., (edited). 1999. Network Exchange Theory. Praeger Publisher, London.

Yin, R.K., 2002. Studi Kasus (Desain dan Metode). Edisi Revisi. Diterjemahkan oleh M. Djauzi Mudzakir. Cet. ke-3, RajaGrafindo Persada, Jakarta. 